\title{
GAYA BELAJAR MAHASISWA PADA MATA KULIAH BAHASA JEPANG BERBASIS ONLINE LEARNING
}

\author{
Sri Muryati ${ }^{1)}$, Bekti Setio Astuti ${ }^{2)}$, Trismanto ${ }^{3)}$ \\ ${ }^{1}$ Fakultas Bahasa dan Budaya,Universitas 17 Agustus 1945 Semarang \\ email: srisensei75@gmail.com \\ ${ }^{2}$ Fakultas Bahasa dan Budaya, Universitas 17 Agustus 1945 Semarang \\ email: astutitaswin@gmaill.com \\ ${ }^{3}$ Fakultas Bahasa dan Budaya, Universitas 17 Agustus 1945 Semarang \\ email: trismanto.tris23@gmaill.com
}

\begin{abstract}
This research is predicated on the problem of learning that is faced by students in university during social distancing due to Coronavirus outbreak. One of the striking problems is most students are not comfortable with e-learning. The aim of this article is grasping the typology of students particularly in e-learning that is conjunction with four aspects namely learning patterns, doing assignments, learning habits and using tools. Furthermore, the other objective is the research will be contributed to lecturers, faculties, universities and policymakers in term of planning, creating, and developing e-learning systems. The methodology used in this research is quantitative with descriptive type where is the population or sample as the object of the research and it is only to describe a variable without comparing to other variables. The result of the study denotes the typology of visual learners dominating learning pattern and doing assignment which was $54 \%$ and 46\% respectively. While in learning habit, the auditory type was the most popular which was $42 \%$ however the kinesthetic type had a low percentage because this activity was rarely carried out in e-learning hence that is why the quantity is negligible.
\end{abstract}

Keywords: auditorial; kinestetik, visual, e-learning

\section{Pendahuluan}

Indonesia dan hampir seluruh negara di dunia mengalami musibah wabah COVID-19 pada awal tahun 2020. Karena adanya wabah COVID-19, perguruan tinggi di Indonesia harus menghadapi keputusan keberlanjutan pembelajaran dan perkuliahan dengan tetap menjaga keamanan dosen, mahasiswa, dan staf akademik dari virus yang terus bergerak cepat. Perkuliahan tatap muka di kelas, praktikum di laboratorium, maupun kuliah lapangan diganti dengan perkuliahan daring. Hal tersebut dimaksudkan untuk membantu pencegahan virus yang menyebabkan COVID-19 (Hodges, Trust, Lockee, \& Bond, 2020). Perpindahan perkuliahan menjadi daring memungkinkan pembelajaran menjadi fleksibel dapat dilaksanakan kapan saja dan di mana saja, namun pembelajaran seperti ini merupakan hal yang baru bagi sebagian civitas academica. Hal itu karena pembelajaran secara daring tidaklah berarti memindahkan perkuliahan tatap muka dengan menggunakan daring, tetapi merubah pembelajaran konvensional yang selama ini dilakukan ke dalam domain pembelajaran dalam jaringan yang serba teknologi. Selain kendala tersebut, terdapat juga asumsi bahwa kualitas dari pembelajaran daring juga dinilai memiliki kualitas yang lebih rendah daripada pembelajaran tatap muka (Hodges, Trust, Lockee, \& Bond, 2020). Meskipun demikian, pembelajaran harus tetap dilaksanakan secara optimal melalui berbagai platform. Terdapat lima hal yang dapat menjadi pertimbangan dosen dalam memilih platform perkuliahan daring (Martin, 2020), yaitu: instruksi, konten, motivasi, hubungan interpersonal 
dosen dan mahasiswa, dan kesehatan mental. Beberapa flatform yang digunakan oleh dosen mengajar Bahasa Jepang adalah google classroom, google meet grup whatsapp, aplikasi zoom meeting. Pada pelaksanaanya ditemukan beberapa kendala, seperti biaya quota internet, dan jaringan telekomunikasi yang kadang-kadang tersendat jika para pengguna terlalu banyak. Selain dari kendala teknis ini, dosen dituntut pula untuk mampu mengembangkan model, strategi, metode dan ketrampilannya dalam pembelajaran dalam jaringan ini. Hal ini menuntut kekreatifan dari dosen untuk selalu meng-upgrading scientific knowledge yang dimiliki agar mampu untuk berkarya dengan menghasilkan produk-produk pembelajaran yang dibutuhkan oleh para mahasiswa. Pembelajaran daring memungkinkan kemandirian belajar mahasiswa meningkat. Kemandirian belajar merupakan aktivitas yang didorong oleh kemauan, pilihan, dan tanggung jawab dari pembelajar dalam hal ini mahasiswa (Pratama \& Pratiwi, 2019). Kegiatan belajar mandiri yang dilakukan mahasiswa memunculkan beberapa tipologi belajar. Gaya belajar adalah kombinasi kemampuan seseorang dalam menyerap, mengatur, dan mengolah informasi belajar (Suparman, 2010). Gaya belajar mahasiswa dapat dikelompokkan menjadi tiga macam yaitu visual, auditori, dan kinestetik (DePorter \& Hermacki, 2007). Tujuan Penelitian ini adalah memetakan gaya belajar mahasiswa pada saat pembelajaran daring terutama pada empat aspek yaitu, pola belajar, pola mengerjakan tugas, kebiasaan, dan alat bantu dengan harapan luarannya dapat digunakan membantu memilih, menyusun dan merancang sistem pembelajaran daring yang tepat dan efektif agar diperoleh hasil yang diharapkan

\section{Kerangka Teori}

Teori yang di gunakan dalam penelitian ini adalah gaya belajar. Menurut S. Suparman (2010:63) Gaya merupakan kombinasi dari bagaimana seorang menyerap, kemampuan mengatur dan mengelolah informasi. Gunawan (2007:138) mendefinisikan gaya belajar sebagai cara yang lebih seseorang sukai dalam melakukan kegiatan berfikir, memproses dan mengerti suatu informasi. Misalnya, jika kita ingin mempelajari mengenai tanaman, apakah kita lebih suka nonton video mengenai tanaman atau mendengarkan ceramah, membaca buku atau mungkin bekerja langsung di perkebunan.

Drummond (1998:186) dikutip oleh Shaffat (2009:41) mendefinisikan gaya belajar sebagai "an individual's preferred mode and desired conditions of learning." Maksudnya, gaya belajar dianggap sebagai cara belajar atau kondisi belajar yang disukai oleh pembelajar. "The learning styles is the way individual students arrange the kinds of information they require." Yang berarti bahwa gaya belajar adalah cara setiap siswa mengatur atau menyusun informasi yang mereka dapatkan (Davidman, 1981:377 dikutip oleh Idi, 2001:1). Gaya belajar juga bisa diartikan dengan cara kita menyerap dan mengatur informasi-informasi berkisar dari yang kongkret (yang berakar pada panca indra ragawi, menekan pada apa yang dapat diamati) hingga yang abstrak (yang berakar pada emosi dan intuisi, menekan pada perasaan dan ide-ide) kendati kebanyakan orang lebih suka pada satu cara khusus (Gregore, 1982) dikutip oleh Glover and Law (2005:90). Selain itu de Porter dan Hernacki (2007:110) berpendapat bahwa gaya belajar adalah kombinasi dari bagaimana seseorang menyerap lalu mengatur dan mengelola informasi. Gaya belajar itu sendiri adalah kunci untuk mengembangkan kinerja dalam pekerjaan, di sekolah dan dalam situasi-situasi antar pribadi, dan ketika kita menyadari bagaimana kita dan orang lain menyerap dan mengelolah informasi yang dapat menjadikan kita belajar dan berkomunikasi lebih mudah dengan gaya kita sendiri.

Brown (2008:128) mendefinisikan gaya pembelajaran sebagai sebuah kecenderungan umum, sukarela atau tidak, untuk melakukan pemrosesan informasi dalam sebuah cara tertentu. Atau dengan kata lain gaya belajar adalah pendekatan pendekatan berbeda atau caracara belajar yang banyak dari kita tentunya menggunakan gaya belajar yang berbeda-beda. Gaya belajar adalah kunci untuk mengembangkan kinerja dalam pekerjaan, di sekolah, dan dalam situasi-situasi antar pribadi. Ketika menyadari bahwa bagaimana seseorang menyerap 
dan mengolah informasi, belajar dan berkomunikasi menjadi sesuatu yang mudah dan menyenangkan (Emirina, 2009:1). Jadi dari beberapa pengertian di atas, gaya belajar adalah cara seseorang dalam menerima, berinteraksi, dan memandang lingkungannya atau didefinisikan sebagai pendekatan yang digunakan peserta didik dalam mempelajari hal baru atau mempelajari berbagai mata pelajaran.

Secara umum gaya belajar dibagi menjadi tiga kelompok, yakni: gaya visual; gaya audiotori dan gaya kinestetik. Gaya belajar visual adalah proses penyampaian informasi kepada pihak lain dengan menggunakan media yang terbaca oleh indera penglihatan. Beberapa pendekataan yang bisa digunakan adalah menyediakan beragam bentuk grafis untuk menyampaikan informasi atau materi pelajaran. Perangkat grafis itu bisa berupa film, slide, gambar ilustrasi, coret-coretan, kartu bergambar, catatan dan kartu-kartu gambar berseri yang bisa digunakan untuk menjelaskan suatu informasi secara berurutan. Gaya belajar auditori adalah gaya belajar dengan cara mendengar. Orang yang memiliki gaya belajar ini, dia lebih banyak menggunakan indera pendengaran. Ada beberapa pendekatan yang bisa dilakukan utuk belajar menggunakan gaya belajar diatas adalah dengan cara Pertama, menggunakan tipe perekam sebagai alat bantu. Alat ini digunakan untuk merekam bacaan atau ceramah yang nantinya bisa 2didengarkan kembali. Kedua, dengan wawancara atau terlibat dalam kelompok diskusi. Ketiga, dengan membaca informasi, kemudian diringkas dalam bentuk lisan dan direkam untuk kemudian didengarkan dan dipahami. Gaya belajar kinestetik adalah gaya belajar dengan cara bergerak, bekerja dan menyentuh. Pendekatan dalam gaya belajar ini adalah belajar melalui pengalaman dengan menggunakan berbagai model atau peraga, bekerja di laboratorium atau bermain sambil belajar dengan cara menjiplak gambar atau kata untuk belajar mengucapkannya atau memahami fakta.

\section{Metode Penelitian}

Metode yang digunakan dalam penelitian adalah penelitian kuantitatif tipe deskriptif. Metode ini dilandaskan pada filsafat positivisme yang digunakan untuk meneliti populasi atau sampel tertentu, adapun pengumpulan data menggunakan instrumen penelitian dan analisis data bersifat kuantitatif/statistic dengan tujuan untuk menguji hipotesis yang telah ditetapkan (Sugiyono, 2012:8). Penelitian ini dilakukan untuk mengetahui nilai variabel mandiri, baik satu variabel atau lebih (independen) tanpa membandingkan atau menghubungkannya dengan variabel lain (Sugiyono, 2012: 13). Jadi, penelitian deskriptif kuantitatif merupakan data yang didapat dari sampel populasi kemudian dianalisis sesuai dengan metode statistik. Adapun tujuan dari penelitian ini adalah untuk mendapatkan gambaran mengenai tipe-tipe belajar yaitu visual, auditorial dan kinestetik dalam pembelajaran daring yang berfokus pada empat aspek pola pembelajaran, pola mengerjakan tugas, kebiasaan dan alat bantu. Penelitian ini dilakukan pada mahasiswa Prodi Bahasa Jepang dengan jumlah sampel sebanyak 13 orang baik laki-laki maupun perempuan.Teknik pengumpulan data yang digunakan adalah kuosioner dengan 10 pertanyaan yang berhubungan dengan tipe belajar visual, auditorial dan kinestetik. Setiap pertanyaan memiliki tiga jawaban yakni A berhubungan dengan visual, B dengan auditorial dan $\mathrm{C}$ dengan kinestetik. Teknik analisis data yang digunakan adalah deskriptif kualifikasi dengan persentase. Selain peneliti menggambarkan data, persentase terhadap hasil angket juga dilakukan untuk mengukur sejauhmana kecenderungan mahasiswa terhadap tiga gaya belajar. Secara teknis peneliti menjumlahkan setiap jawaban mahasiswa dan memisahkan mana yang termasuk jawaban $\mathrm{A}, \mathrm{B}$, dan $\mathrm{C}$ kemudian mencari nilai persentasi dari jawaban $\mathrm{A}, \mathrm{B}$, dan $\mathrm{C}$ dengan cara membagi jumlah jawaban ketiganya dengan skor maksimum ideal setelah itu dikali 100 . 


\section{Hasil dan Pembahasan}

\subsection{Hasil}

Partisipan pada penelitian ini yaitu mahasiswa program studi Bahasa Jepang sebanyak 13 orang yang terdiri dari 4 mahasiswa laki laki dan 9 mahasiswa perempuan semester 1 tahun ajaran 2020/2021

\section{Partisipan berdasarkan Jenis Kelamin}

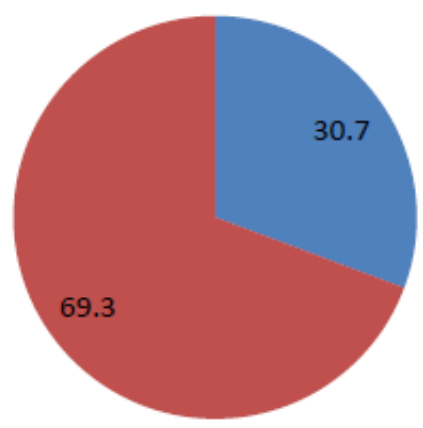

laki laki

Perempuan

Hasil penelitian ini berdasarkan atas jawaban dari setiap pertanyaan dengan pemaparan sebagai berikut:

Tabel 1. Pola Belajar Mahasiswa

\begin{tabular}{|l|c|c|}
\hline \multicolumn{1}{|c|}{ Kategori } & Frekuensi & Presentasi \\
\hline Visual & 7 & $54 \%$ \\
\hline Auditori & 4 & $31 \%$ \\
\hline Kinestetik & 2 & $15 \%$ \\
\hline
\end{tabular}

Berdasarkan Tabel 1 di atas, mahasiswa program studi Bahasa Jepang lebih menyukai pembelajaran secara visual melalui teks, grafis,gambar, foto, audio, video dan animasi yaitu sebnayak 7 orang atau 53,8. Mahasiswa yang menyukai pembelajaran daring secara auditori melalui teleconference atau mendengarkan penjelasan dari dosen sebanyak 4 orang atau $30.7 \%$. Hal ini dikarenakan kendala sinyal internet sehingga terdapat mahasiswa yang kesulitan mendengar pembicaraan dosen secara langsung karena terdapat delay.

Sedangkan mahasiswa yang menyukai pembelajaran daring secara kinestetik melalui kegiatan mengoperasikan konten konten pada aplikasi, menggerakkan perangkat pada computer sebanyak 2 orang atau $15.5 \%$.

Tabel 2. Pola Mengerjakan Tugas Mahasiswa

\begin{tabular}{|l|c|c|}
\hline \multicolumn{1}{|c|}{ Kategori } & Frekuensi & Presentasi \\
\hline Visual & 3 & $23 \%$ \\
\hline Auditori & 4 & $31 \%$ \\
\hline Kinestetik & 6 & $46 \%$ \\
\hline
\end{tabular}



Muryati, Bekti Setio Astuti, Trismanto)

Tabel 2 menunjukkan pola mengerjakan tugas mahasiswa selama pembelajaran daring. Sebanyak 3 orang mahasiswa atau 23\%, menyukai tugas yang bersifat visual melalui tugas tugas yang berbentuk tulisan. Sebayak 4 orang, $31 \%$ menyukai tugas yang berbentuk auditori yang berupa tugas dalam bentuk diskusi,wawancara, atau teleconference. Sebanyak 6 orang ( $46 \%$ ), menyukai tugas yang bersifat kinestetik berupa tugas praktik seperti membuat video atau konten.

\section{Tabel 3. Kebiasaan Mahasiswa Selama Pembelajaran Daring}

\begin{tabular}{|l|c|c|}
\hline \multicolumn{1}{|c|}{ Kategori } & Frekuensi & Presentasi \\
\hline Visual & 3 & $23 \%$ \\
\hline Auditori & 7 & $54 \%$ \\
\hline Kinestetik & 3 & $23 \%$ \\
\hline
\end{tabular}

\section{Tabel 3. Kebiasaan Mahasiswa Selama Pembelajaran Daring}

\begin{tabular}{|l|c|c|}
\hline \multicolumn{1}{|c|}{ Kategori } & Frekuensi & Presentasi \\
\hline Visual & 3 & $23 \%$ \\
\hline Auditori & 7 & $54 \%$ \\
\hline Kinestetik & 3 & $23 \%$ \\
\hline
\end{tabular}

Dari tabel 3 dapat diketahui bahwa 3 mahasiswa atau 23\%, menyukai kebiasaan kategori visual yaitu membaca tugas yang diberikan berupa PDF, slide power point, dan e-book . Sebanyak 7 mahasiswa (54\%) menyukai kebiasaan kategori auditori dengan mendengarkan dosen langsung melalui teleconference. Sebanyak 3 mahasiswa (23\%) menyukai kebiasaan kategori kinestetik melalui aktivitas bergerak atau membuat kreasi.

Tabel.4. Kesulitan Mahasiswa Selama Pembelajaran Daring

\begin{tabular}{|l|c|c|}
\hline \multicolumn{1}{|c|}{ Jenis Kesulitan } & Frekuensi & Presentasi \\
\hline Mengingat informasi yang diberikan secara lisan & 1 & $8 \%$ \\
\hline $\begin{array}{l}\text { Menuliskan informasi yang dijelaskan tetapi tidak } \\
\text { mampu memahaminya }\end{array}$ & 2 & $15 \%$ \\
\hline $\begin{array}{l}\text { Memahami hal hal yang berkaitan dengan symbol } \\
\text { yaitu huruf kanji }\end{array}$ & 10 & $77 \%$ \\
\hline
\end{tabular}

Berdasarkan Tabel 4 jenis kesulitan yang dialami oleh mahasiswa didominasi oleh sulitnya memahami hal hal yang berkaitan dengan symbol atau huruf kanji dalam bahasa Jepang, yaitu sebanyak 10 mahasiswa atau $77 \%$, Selanjutnya adalah mahasiswa yang mengalami kesulitan untuk menuliskan informasi yang telah dijelaskan dosen namun belum mampu memahaminya sebanyak 2 orang (15\%). Dan kesulitan terakhir adalah mengingat informasi yang diberikan secara lisan dalam pembelajaran daring yaitu sebanyak 1 mahasiswa (8\%). 
Tabel 5. Minat Mahasiswa dalam Memilih Alat Bantu Pembelajaran Daring

\begin{tabular}{|l|c|c|}
\hline \multicolumn{1}{|c|}{ Kategori } & Frekuensi & Presentasi \\
\hline Visual & 6 & $46 \%$ \\
\hline Auditori & 6 & $46 \%$ \\
\hline Kinestetik & 1 & $8 \%$ \\
\hline
\end{tabular}

Tabel 5 di atas merupakan tabel alat bantu yang digunakan oleh mahasiswa selama pembelajaran daring. Terdapat 6 mahasiswa (46\%) memilih alat bantu kategori visual berupa gambar, video, dan ilustrasi visual lainnya. Sebanyak 6 mahasiswa (46\%) memilih alat bantu kategori auditori berupa podcast, audio, dan rekaman pembiacaraan atau penjelasan. Sebanyak 1 mahasiswa (8\%) memilih alat bantu kategori kinsetetik berupa objek nyata.

Tabel 6. Aktivitas yang Kurang Disukai Selama Pembelajaran Daring

\begin{tabular}{|l|c|c|}
\hline \multicolumn{1}{|c|}{ Kategori } & Frekuensi & Presentasi \\
\hline Visual & 2 & $15 \%$ \\
\hline Auditori & 6 & $47 \%$ \\
\hline Kinestetik & 5 & $38 \%$ \\
\hline
\end{tabular}

Berdasarkan Tabel 6 di atas mahasiswa yang kurang menyukai aktivitas pembelajaran daring dengan penjelasan secara langsung, video, atau, audio sebanyak 2 orang (15\%). Mahasiswa yang kurang menyukai aktivitas pembelajaran daring dengan pemberian tugas membaca sebanyak 6 orang atau $47 \%$. Mahasiswa yang kurang menyukai pembelajaran daring dengan berdiam diri tanpa aktivitas sebanyak 5 orang atau $38 \%$.

Tabel 7. Tempo dalam Presentasi Makalah dalam Pembelajaran Daring

\begin{tabular}{|l|c|c|}
\hline \multicolumn{1}{|c|}{ Tempo } & Frekuensi & Presentasi \\
\hline Cepat & 0 & $0 \%$ \\
\hline Sedang & 12 & $92 \%$ \\
\hline Lambat & 1 & 8 \\
\hline
\end{tabular}

Tabel 7 merupakan tabel kecenderungan tempo mahasiswa terhadap bentuk presentasi makalah yang disimak pada saat mahasiswa lain sedang mempresentasikannya dalam pembelajaran daring. Tidak terdapat mahasiswa atau 0\% yang menyukai tempo presentasi yang cepat. Sedangkan tempo presentasi sedang disukai sebanyak 12 orang atau $92 \%$. Satu mahasiswa atau $8 \%$ menyukai tempo presentasi yang lambat 
Gaya Belajar Mahasiswa pada Mata Kuliah Bahasa Jepang Berbasis Online Learning (Sri Muryati, Bekti Setio Astuti, Trismanto)

Tabel 8. Sikap Mahasiswa dalam Menyiapkan Presentasi Makalah

\begin{tabular}{|l|c|c|}
\hline \multicolumn{1}{|c|}{ Sikap } & Frekuensi & Presentasi \\
\hline $\begin{array}{l}\text { Pengeja yang baik, dapat melihat kata kata yang } \\
\text { sebenarnya dalam pikiran }\end{array}$ & 7 & $53 \%$ \\
\hline $\begin{array}{l}\text { Lebih pandai mengeja dengan keras daripada } \\
\text { menuliskannya }\end{array}$ & 4 & $31 \%$ \\
\hline Lebih pandai melakukan sesuatu yang meyibukkan & 2 & $14 \%$ \\
\hline
\end{tabular}

Tabel 8 merupakan sikap mahasiswa dalam menyiapkan presentasi makalah dengan kegiatan membaca buku. Sebanyak 7 mahasiswa (53\%) merupakan pengeja yang baik dan dapat melihat kata-kata yang sebenarnya ketika membaca buku. Sebanyak 4 mahasiswa (31\%) lebih pandai mengeja dengan keras daripada menuliskannya ketika membaca buku. Sebanyak 2 mahasiswa atau 14\%, lebih pandai melakukan sesuatu yang meyibukkan ketika membaca buku.

Tabel.9. Kondisi Mahasiswa Saat Daring Melalui Platform Video

\begin{tabular}{|l|c|c|}
\hline \multicolumn{1}{|c|}{ Kondisi } & Frekuensi & Presentasi \\
\hline Tidak mudah terganggu oleh keributan di sekitar & 3 & $23 \%$ \\
\hline Mudah terganggu oleh keributan di sekitar & 7 & $54 \%$ \\
\hline Biasa saja & 3 & $23 \%$ \\
\hline
\end{tabular}

Tabel 9 di atas adalah tabel yang menunjukkan kondisi atau perasaan mahasiswa ketika belajar daring secara langsung dengan dosen melalui platform video. Sebanyak 3 mahasiswa atau 23\% merasa tidak mudah terganggu oleh kesibukan di sekitar. Sebanyak 7 mahasiswa atau 54\% merasa mudah terganggu oleh keributan di sekitar, dan sebanyak 3 mahasiswa atau $23 \%$ merasa biasa saja saat pembelajaran daring melalui video dengan dosen.

Tabel 10. Minat Mahasiswa Terhadap Huruf Jepang

\begin{tabular}{|l|c|c|}
\hline \multicolumn{1}{|c|}{ Minat } & Frekuensi & Presentasi \\
\hline Lebih menyukai kanji daripada hiragana & 2 & $15 \%$ \\
\hline Lebih menyukai hiragana daripada katakana & 9 & $70 \%$ \\
\hline Lebih menyukai katakana daripada hiragana & 2 & $15 \%$ \\
\hline
\end{tabular}

Berdasarkan table 10 diatas, mahasiswa yang lebih menyukai kanji dari pada hiragana sebanyak 2 orang atau 15\%. Sebanyak 9 mahasiswa atau $70 \%$ lebih menyukai hiragana daripada katakana. Mahasiswa yang menyukai katakana dibanding hiragana adalah 2 orang atau $15 \%$. 


\subsection{Pembahasan}

Hasil temuan dalam penelitian ini adalah mahasiswa mahasiswa lebih menyukai aspek visual selama pembelajaran daring dengan persentase mahasiswa memilih aspek visual dalam tiga pernyataan lebih tinggi daripada persentase aspek lainnya, kecuali pada kebiasaan mahasiswa dalam pembelajaran daring. Rekapitulasi keempat pernyataan dapat dilihat pada tabel berikut.

Tabel 11. Rekapitulasi Gaya Belajar Mahasiswa dalam Pembelajaran Daring

\begin{tabular}{|l|l|l|l|l|}
\hline \multirow{2}{*}{ Aspek } & \multicolumn{4}{|c|}{ Presentase } \\
\cline { 2 - 5 } & Pola Belajar & $\begin{array}{l}\text { Pola Mengerjakan } \\
\text { Tugas }\end{array}$ & Kebiasaan & $\begin{array}{l}\text { Alat } \\
\text { Bantu }\end{array}$ \\
\hline Visual & $54 \%$ & $23 \%$ & $23 \%$ & $46 \%$ \\
\hline Auditori & $31 \%$ & $31 \%$ & $54 \%$ & $46 \%$ \\
\hline Kinestetik & $15 \%$ & $46 \%$ & $23 \%$ & $8 \%$ \\
\hline
\end{tabular}

Aspek visual adalah salah satu gaya belajar mahasiswa dalam mempelajari materi perkuliahan melalui penglihatan dan pengamatan (Bire, Geradus, \& Bire, 2014). Pada pembelajaran daring ini, interaksi mahasiswa dengan dosen lebih banyak dilakukan melalui penyajian gambar, teks, slide presentasi power point, dan video yang bersifat visual. Sehingga gaya belajar atau tipologi mahasiswa didominasi oleh aspek visual. Mahasiswa pembelajar visual lebih suka belajar melalui saluran visual seperti platform yang banyak digunakan dosen pada pembelajaran daring. Karena itu mahasiswa membutuhkan stimulasi visual video dan film (Gholami \& Bagheri, 2013).

Selanjutnya pola mengerjakan tugas mahasiswa banyak menggunakan aspek kinestetik. Sedangkan pada kebiasaan dan pemilihan alat bantu, aspek auditori metupakan aspek yang paling diminati. Kebiasaan kegiatan teleconference dosen dan mahasiswa lebih banyak disukai. Mahasiswa ingin terlibat dalam diskusi dan percakapan sehingga membutuhkan arahan lisan (Oxford, 1995). Sistem pembelajaran daring dapat mengoptimalkan interaksi antara dosen dan mahasiswa melalui forum diskusi yang terdapat pada media. Pada pembelajaran daring aspek kinestetik sedikit diminati oleh mahasiswa baik karena aktivitas kinesteik belum memungkinkan digunakan dalam pembelajaran daring. Mahasiswa belum memungkinkan untuk melakukan praktik. Mahasiswa pembelajar kinestetik adalah mahasiswa yang paling banyak melakukan aktivitas praktik (Sujono, 2014). Padahal pada pembelajaran di kelas, gaya kinestik lebih berpengaruh terhadap prestasi belajar mahasiswa (Bire, Geradus, \& Bire, 2014; Vaishnav, 2013).

Salah satu kegiatan perkuliahan yang dilakukan selama pembelajaran daring adalah presentasi makalah. Dalam menyiapkan presentasi makalah, mahasiswa terlebih dahulu membaca pokok bahasan yang akan disampaikan. Terdapat beberapa tipe dalam membaca: 1) pengeja yangbaik hanya dengan melihat kata-kata pada buku, 2) mengeja dengan keras, dan 3) menuliskan kembali ketika membaca buku. Tipe yang mendominasi adalah pengeja yang baik hanya dengan membaca buku. Sejalan dengan hasil penelitian bahwa kategori visual lebih mendominasi. Pembelajar visual lebih suka belajar dengan banyak membaca yang membutuhkan konsentrasi dan waktu yang dihabiskan sendirian (Gholami \& Bagheri, 2013). Tempo sedang lebih banyak disukai mahasiswa pada saat menyimak mahasiswa lain yang sedang mempresentasikan makalah.

Aktivitas pembelajaran yang paling tidak diminati mahasiswa selama pembelajaran daring adalah dengan pemberian tugas. Selain itu, mahasiswa kurang menyukai pembelajaran daring dengan berdiam diri tanpa aktivitas. Penjelasan dari dosen secara langsung pada pembelajaran daring ini dibutuhkan oleh mahasiswa (Yuhdi \& Amalia, 2020). Adanya tugas 
yang menumpuk merupakan salah satu hambatan yang dirasakan mahasiswa selama pembelajaran daring (Jamaluddin, Ratnasih, Gunawan, \& Paujiah, 2020). Pemberian tugas oleh dosen sebaiknya mempertimbangkan kondisi mahasiswa.

Selama proses pembelajaran daring mahasiswa mengalami beberapa hambatan dan kesulitan. Kesulitan yang dialami oleh mahasiswa yaitu dalam mengingat informasi yang diberikan oleh dosen dan memahami hal-hal yang bersifat abstrak. Untuk itu diperlukan adanya sebuah evaluasi proses pelaksanaan pembelajaran yang dilakukan oleh dosen. Evaluasi ini digunakan untuk memprediksikan suatu rancangan penerapan pembelajaran yang tepat untuk mengatasi kesulitan dengan solusi yang ditawarkan berdasarkan kompenen context, input, process, dan product (Riyanda, Herlina, \& Wicaksono, 2020).

Hambatan lain yang dialami mahasiswa berkaitan dengan kondisi atau perasaan mahasiswa pada saat pembelajaran daring secara langsung dengan dosen melalui platform video. Mahasiswa merasa mudah terganggu oleh keributan di sekitar. Artinya kondisi lingkungan belajar di sekitar mahasiswa memengaruhi proses pembelajaran. Kondisi lingkungan merupakan hal yang penting dalam pembelajaran daring (Carlen, 2020).

Selanjutnya adalah minat mahasiswa terhadap pembelajaran huruf Jepang secara daring sebagian besar lebih menyukai belajar menggunakan hiragana dibandingkan dengan katakana dan kanji, Dalam bahasa Jepang, digunakan 4 huruf yaitu hiragana, katakana, romaji dan kanji. Huruf Kanji merupakan salah satu aspek yang sulit bagi para siswa yang mempelajari bahasa Jepang, terutama bagi siswa yang tidak mempunyai latar belakang budaya Kanji. Bahkan bagi para siswa yang mempunyai latar belakang Kanji pun kadang-kadang menganggap sulit bila berhadapan dengan Kanji Jepang. (Dahidi Ahmad dan Sudjianto, 2004, hlm.56). Alasannya adalah karena aturan penulisan, cara baca dan menghapalkannya.Sehingga ketika pembelajaran daring, mahasiwa sering melakukan kesalahan dalam menulikan kanji dosen tidak bisa secara langsung berinteraksi dalam melakukan koreksi.

\section{Simpulan}

Kecepatan pembahasan materi secara offline berbeda dengan kecepatan pembahasan materi secara online (daring) sehingga terdapat kemungkinan, beberapa materi tidak sempat dibahas selama periode perkuliahan. Selain masalah waktu, mahasiswa bukan tidak mungkin mengalami kesulitan untuk menangkap materi karena ada beberapa gangguan yang terjadi selama kuliah daring. Kuliah daring memberikan dampak, baik positif maupun negatif, bagi dosen dan mahasiswa. Hal penting yang perlu diperhatikan, bagaimana dampaknya terhadap materi pembelajaran dan apakah dengan diadakannya kuliah daring, perkuliahan tetap berjalan sesuai dengan yang direncanakan (online). Hasil penelitian menunjukan bahwa gaya belajar pada pola belajar dan pemilihan alat bantu didominasi oleh tipe visual. Sedangkan pola mengerjakan tugas mahasiswa lebih menyukai tipoe auditori. Berbeda dengan tipe kinestetik, jumlah mahasiswa relatif sedikit baik pada pola pembelajaran, pola mengerjakan tugas, kebiasaan dan alat bantu Akan tetapi bisa jadi hal ini terjadi dikarenakan aktivitas gerak jarang dilakukan pada pembelajaran daring sehingga jumlahnya tidak signifikan.

\section{Referensi}

Arianty, Dini. (2020). Belajar dari Covid-19 dalam Pengalaman Baik Mengajar dari Rumah di Masa Pandemi Covid-19 Mata Pelajaran Matematika (e-book). Jakarta:Kemdikbud.

Arikunto, Suharsimi. (2013). Prosedur Penelitian: Suatu Pendekatan Praktik. Jakarta:Rineka Cipta.

Bire, A. L., Geradus, U., \& Bire, J. (2014). Pengaruh gaya belajar visual, auditorial, dan kinestetik terhadap prestasi belajar siswa. Jurnal Kependidikan, 168-174. 
Carlen, U. (2020, April 29). Typology of Online Learning Communities. Retrieved from Research Gate:

Nazir, Moh. (2014). Metode Penelitian, Jakarta: Ghalia Indonesia

Nurhayati, E. (2020). Meningkatkan Keaktifan Siswa Dalam Pembelajaran Daring Melalui Media Game Edukasi Quiziz pada Masa Pencegahan Penyebaran Covid-19. Jurnal Paedagogy, 7(3), 145-150

Pusptasari, Dewi. (2020). Praktik Baik Pembelajaran di Rumah bagi Guru dalam

Pengalaman Baik Mengajar dari Rumah di Masa Pandemi Covid-19 Mata Pelajaran Bahasa Inggris (e-book). Jakarta: Kemdikbud.

Sugiyono. (2010). Metode Penelitian Kuantitatif, Kualitatif dan R \& D. Bandung: Alfabeta

Susani, Arie. (2020). Layanan Pembelajaran di Rumah saat Pandemi Covid-19 dalamPengalaman Baik Mengajar dari Rumah di Masa Pandemi Covid-19 Mata Pelajaran Bahasa Inggris (e-book). Jakarta: Kemdikbud.

Susilowati. (2020). Pengalaman Baik Pembelajaran di Rumah Mata Pelajaran Bahasa Indonesia di SMPN 6 Semarang dalam Pengalaman Baik Mengajar dari Rumah di Masa Pandemi Covid-19 Mata Pelajaran Bahasa Indonesia (e-book). Jakarta: Kemdikbud. www.researchgate.net/publication/228595671_Typology_of_online_learning_communities 